\title{
ОСОБЛИВОСТІ КІЛЬКІСНИХ МОРФОЛОГІЧНИХ ЗМІН АРТЕРІЙ ТОВСТОї КИШКИ ПРИ РЕЗЕКЦІЯХ РІЗНИХ ОБ'ЄМІВ ПАРЕНХІМИ ПЕЧІНКИ
}

\author{
๑М. С. Гнатюк, О. М. Процайло, Л. В. Татарчук, Н. Я. Монастирська \\ Тернопільський національний медичний університет імені І. Я. Горбачевського МОЗ України
}

РЕЗЮМЕ. Видалення великих об'ємів печінки призводить до портальної гіпертензії, кровотеч із варикозно розширених вен стравоходу, шлунка, прямої кишки, асциту, спленомегалії та структурної перебудови органів басейну ворітної печінкової вени. Товста кишка - орган, венозний дренаж від якого здійснюється через ворітну печінкову вену і гемодинамічні розлади у ній ускладнюються різними структурно-функціональними змінами, а морфологія артеріального русла товстої кишки при резекції різних обсягів печінки вивчена недостатньо.

Мета - кількісними морфологічними методами вивчити особливості структурної перебудови артерій товстої кишки при резекції різних об'ємів паренхіми печінки.

Матеріал і методи. Морфологічно досліджені артерії товстої кишки 60 щурів, які були поділені на три групи. 1 група - 20 інтактних тварин, 2 - 20 щурів після видалення 31,5 \% паренхіми печінки, 3 - 20 тварин після резекції 58,1 \% паренхіми печінки. Евтаназія тварин здійснювалася кровопусканням в умовах тіопенталового наркозу через 1 місяць від початку досліду. Із товстої кишки виготовляли мікропрепарати, на яких морфометрично визначали зовнішній та внутрішній діаметри артерій середнього та дрібного калібрів, товщину медії, адвентиції, висоту ендотеліоцитів, діаметр їх ядер, ядерно-цитоплазматичні відношення у цих клітинах, відносний об'єм пошкоджених ендотеліоцитів. Кількісні показники обробляли статистично.

Результати. Встановлено, що видалення 58,1 \% паренхіми печінки призводило до розвитку пострезекційної портальної гіпертензії і вираженої структурної перебудови переважно артерій дрібного калібру товстої кишки, яка характеризувалася значним зростанням товщини їх стінки, медії та адвентиції, зменшенням просвітів на $26,6 \%$, індексу Керногана - на 52,3 \% (р<0,001). Ядерно-цитоплазматичні відношення в ендотеліоцитах при цьому зросли на 7,5 \%, (p<0,01), відносний об'єм пошкоджених ендотеліоцитів - у 14,5 раза ( $<<0,001)$.

Висновки. Видалення лівої та правої бокових часток печінки у білих щурів призводить до пострезекційної портальної гіпертензії та вираженого ремоделювання переважно артерій дрібного калібру товстої кишки, яке характеризується потовщенням їхньої стінки, звуженням просвіту, зниженням індексу Керногана, ураженням ендотеліоцитів, ендотеліальною дисфункцією, погіршанням кровопостачання органа, гіпоксією, дистрофією, некрозом тканин і клітин, вогнищевими клітинними інфільтратами, склерозуванням.

КлючОВІ СлОВА: резекція печінки; товста кишка; артерії; морфометрія.

Вступ. Резекцію печінки сьогодні нерідко виконують у хірургічних стаціонарах. Показаннями до цієї операції є доброякісні та злоякісні пухлини, метастази, травми печінки, внутрішньопечінковий холангіолітіаз, альвеолярний ехінококоз, трансплантація печінки тощо $[2,8,9]$. Резекція великих об'ємів печінки може призводити до різних пострезекційних ускладнень: кровотечі з варикозно розширених вен стравоходу, шлунка, прямої кишки, асциту, спленомегалії, вторинного гіперспленізму, паренхіматозної жовтяниці, портосистемної енцефалопатії, печінкової недостатності, гепаторенального синдрому, поліорганної недостатності, портальної гіпертензії. Пострезекційна портальна гіпертензія призводить до структурної перебудови судин та органів басейну ворітної печінкової вени, до яких належить товста кишка $[3,7]$. Сьогодні морфометричні методи широко застосовують для вивчення ангіоархітектоніки інтраорганного судинного русла неушкоджених органів та при різних патологічних станах, де переважно локалізовані складні процеси взаємовідношень крові, тканин та клітин [1]. Інтраорганні артерії відіграють важливу роль у кровопоста- чанні органів, порушення якого та структурні зміни артеріальних судин призводять до виражених змін кровообігу, що суттєво впливає на повноцінність функціонування органів і систем $[3,4]$. Варто зазначити, що артеріальні судини товстої кишки при резекції різних об'ємів паренхіми печінки досліджені недостатньо.

Мета - кількісними морфологічними методами вивчити особливості структурної перебудови артерій товстої кишки при резекції різних об'ємів паренхіми печінки.

Матеріал і методи дослідження. Комплексом морфологічних методів досліджені артерії товстої кишки 60 лабораторних білих статевозрілих щурів-самців, які були поділені на 3-и групи. 1-а група нараховувала 20 інтактних тварин (контрольна), 2-а - 20 щурів після резекції лівої бокової частки - 31,5 \% паренхіми печінки, 3-я - 20 тварин після видалення правої і лівої бокових часток печінки (58,1%) [4]. Евтаназію тварин здійснювали кровопусканням в умовах тіопентал-натрієвого наркозу через 1 місяць від початку експерименту. Шматочки товстої кишки після фіксації, проведення через етилові спирти зростаючої концентрації 
Огляди літератури, оригінальні дослідження, погляд на проблему, випадок з практики, короткі повідомлення поміщали у парафін. Гістологічні зрізи товщиною 5-7 мкм після депарафінізації фарбували гематоксиліном-еозином, за ван Гізон, Маллорі, Вейгертом, толуїдиновим синім [5]. На гістологічних мікропрепаратах товстої кишки вимірювали зовнішній (ДЗ) та внутрішній (ДВ) діаметри артерій середнього (зовнішній діаметр (51-125 мкм), дрібного (зовнішній діаметр 26-50 мкм) калібрів, товщину медії (TM), адвентиції (ТА), індекс Керногана (IK), висоту ендотеліоцитів (BE), діаметр їх ядер (ДЯ), ядерно-цитоплазматичні відношення (ЯЦВ) у цих клітинах, відносний об'єм пошкоджених ендотеліоцитів (ВОПЕ) $[1,4]$. Отримані кількісні показники обробляли статистично. Обробка отриманих результатів виконана у відділі системних статистичних досліджень Тернопільського національного медичного університету імені І. Я. Горбачевського МO3 України в програмному пакеті STATISTICA. Різницю між порівнюваними величинами визначали за критеріями Стьюдента та Манна-Уітні [6]. Експерименти та евтаназію дослідних тварин проводили з дотриманням «Загальних етичних принципів експериментів на тваринах», ухвалених Першим національним конгресом з біоетики (Київ, 2001) відповідно до «Європейської конвенції про захист хребетних тварин, що використовуються у дослідних та інших наукових цілях", а також Закону України «Про захист тварин від жорстокого поводження» (від 21.02.2006).

Результати й обговорення. Проведеними дослідженнями встановлено, що резекція 31,5 \% паренхіми печінки не призводила до суттєвих гемодинамічних змін у системі печінкової ворітної вени. Більшість досліджуваних морфометричних параметрів артеріального русла товстої кишки при цьому не змінювалися (табл. 1). У вказаних умовах експерименту в артеріях середнього калібру виявлено зростання відносного об'єму пошкоджених ендотеліоцитів у 1,5 раза $(p<0,001)$, а в артеріях дрібного калібру - у $1,8$ раза ( $p<0,001)$, товщина адвентиції у цих артеріях зросла на 2,8 \% $(p<0,05)$ переважно за рахунок набряку строми. Пошкодження ендотеліоцитів можна пов'язати зі зростанням кількості апоптично змінених клітин.

Виявлено, що резекція лівої та правої бокових часток печінки (58,1 \% її паренхіми) призводила до пострезекційної портальної гіпертензії, яка характеризувалася розширенням ворітної печінкової вени, повнокров'ям і розширенням брижових вен, видимого венозного русла тонкої та товстої кишок, спленомегалією, асцитом. Виявлене свідчило про наявність пострезекційної портальної гіпертензії. Усестороннім аналізом даних вказаної таблиці встановлено, що досліджувані кількісні морфологічні показники переважно у 3 групі спостережень виражено змінювалися, порівняно з контрольними величинами.

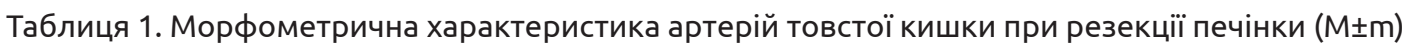

\begin{tabular}{|c|c|c|c|}
\hline \multirow{2}{*}{ Показник } & \multicolumn{3}{|c|}{ Група спостереження } \\
\hline & 1 & 2 & 3 \\
\hline \multicolumn{4}{|c|}{ Артерії середнього калібру } \\
\hline ДЗ, мкм & $82,30 \pm 0,63$ & $82,60 \pm 0,66$ & $84,60 \pm 0,54^{*}$ \\
\hline ДВ, мкм & $31,60 \pm 0,34$ & $31,40 \pm 0,42$ & $30,10 \pm 0,33^{*}$ \\
\hline TM, MKM & $20,30 \pm 0,12$ & $20,35 \pm 0,18$ & $21,40 \pm 0,21 *$ \\
\hline TA, MKM & $24,21 \pm 0,15$ & $24,40 \pm 0,21$ & $26,90 \pm 0,21 * * *$ \\
\hline $\mathrm{IK}, \%$ & $14,70 \pm 0,12$ & $14,45 \pm 0,15$ & $12,60 \pm 0,12^{* * *}$ \\
\hline $\mathrm{BE}, \mathrm{MKM}$ & $6,15 \pm 0,03$ & $6,12 \pm 0,03$ & $6,20 \pm 0,06$ \\
\hline ДЯЕ, МКМ & $3,20 \pm 0,02$ & $3,19 \pm 0,03$ & $3,26 \pm 0,03$ \\
\hline ЯЦВ & $0,270 \pm 0,002$ & $0,272 \pm 0,003$ & $0,278 \pm 0,003 *$ \\
\hline BОПЕ, \% & $2,20 \pm 0,03$ & $3,30 \pm 0,03 * * *$ & $8,20 \pm 0,30 * * *$ \\
\hline \multicolumn{4}{|c|}{ Артерії дрібного калібру } \\
\hline ДЗ, мКм & $34,10 \pm 0,18$ & $34,21 \pm 0,21$ & $36,30 \pm 0,21 * * *$ \\
\hline ДВ, мКМ & $12,40 \pm 0,12$ & $12,35 \pm 0,12$ & $9,10 \pm 0,09 * * *$ \\
\hline TM, MKM & $9,30 \pm 0,06$ & $9,32 \pm 0,06$ & $12,20 \pm 0,09 * * *$ \\
\hline TA, MKM & $6,30 \pm 0,03$ & $6,48 \pm 0,06 *$ & $9,02 \pm 0,06 * * *$ \\
\hline $\mathrm{IK}, \%$ & $13,20 \pm 0,12$ & $13,04 \pm 0,12$ & $6,30 \pm 0,06 * * *$ \\
\hline $\mathrm{BE}, \mathrm{MKM}$ & $6,10 \pm 0,03$ & $6,05 \pm 0,04$ & $5,90 \pm 0,03^{*}$ \\
\hline ДЯЕ, мКМ & $3,15 \pm 0,02$ & $3,12 \pm 0,03$ & $3,20 \pm 0,03$ \\
\hline ЯЦВ & $0,265 \pm 0,002$ & $0,266 \pm 0,003$ & $0,285 \pm 0,003 * *$ \\
\hline ВОПЕ, \% & $2,30 \pm 0,02$ & $4,15 \pm 0,03 * * *$ & $33,30 \pm 0,24 * * *$ \\
\hline
\end{tabular}

Примітка. *- $p<0,05 ;{ }^{* *}-p<0,01 ;$ *** $-p<0,001$ порівняно з 1-ю групою. 
Огляди літератури, оригінальні дослідження, погляд на проблему, випадок з практики, короткі повідомлення

При цьому структура артерій середнього та дрібного калібрів змінювалася, що підтверджувалося досліджуваними морфометричними показниками. Так, зовнішній діаметр артерій середнього калібру виявився збільшеним на 2,8 \% ( $<<0,05)$, порівняно з контролем, товщина медії - на 5,4 \%, товщина адвентиції - на 11,1 \% (p<0,001), просвіт досліджуваних судин та індекс Керногана зменшилися відповідно на 4,7 \% та 14,3\% (p<0,001). Потовщення стінки вказаних артерій, зменшення їх просвіту та індексу Керногана свідчило про зниження пропускної спроможності цих судин та погіршання кровопостачання досліджуваного органа [4].

Висота ендотеліоцитів артерій середнього калібру товстої кишки при пострезекційній портальній гіпертензії зросла всього на 0,8 \%, а діаметр їх ядер - на 1,8 \% ( $>>0,05)$. Майже на 3,0 \% ( $<<0,05)$ змінилися при цьому ядерно-цитоплазматичні відношення, що свідчило про порушення структурного клітинного гомеостазу. Деякі дослідники вважають зміни співвідношень між параметрами ядра та цитоплазми клітин порушенням або зривом структурного клітинного гомеостазу $[1,4]$. Виявлено також, що чим більше змінений вказаний морфометричний параметр, тим вираженіші структурні зміни у клітинах та тканинах ураженого органа. Отримані результати проведеного дослідження свідчать, що ядерно-цитоплазматичні відношення у клітинах $\epsilon$ важливими показниками, які відображають не лише зв'язки між ядром та цитоплазмою, а й дозволяють також судити про соматичний цитогенез, функціональний стан та структуру клітини $[1,4,11]$. Відносний об'єм пошкоджених ендотеліоцитів у артеріях середнього калібру товстої кишки при цьому зріс у 3,7 раза.

Ступінь ремоделювання артерій дрібного калібру товстої кишки в умовах пострезекційної портальної гіпертензії був виражений більше, порівняно з артеріями середнього калібру. Так, зовнішній діаметр вказаних судин при цьому зріс на $6,45 \%$ ( $><0,001)$, товщина медії - на 31,2\%, адвентиції - на 43,2 \% ( $<<0,001)$. Внутрішній діаметр (просвіт) вказаних артерій у досліджуваних експериментальних умовах статистично достовірно $(p<0,001)$ зменшився на 26,6 \%, а індекс Керногана - на $52,2 \%(p<0,001)$.

Висота ендотеліоцитів артерій дрібного калібру товстої кишки при пострезекційній портальній гіпертензії статистично достовірно $(p<0,05)$ зменшилася на 3,3 \%, діаметр їх ядер змінився незначно, а ядерно-цитоплазматичні відношення у ендотеліоцитах зросли на 7,5 \% (p<0,01). Відносний об'єм пошкоджених ендотеліоцитів у артеріях дрібного калібру товстої кишки через місяць після видалення 58,1 \% паренхіми печінки з вираженою статистично достовірною різницею $(p<0,001)$ зріс у
14,5 раза. Відомо, що ендотеліоцити судин продукують різні біологічно активні речовини, необхідні для регуляції життєво важливих процесів організму. Вони здійснюють бар'єрну, продукційну, гемостатичну, метаболічну, транспортну, репаративну функції, синтезують оксид азоту (NO), ендотелін, ангіотензин-ІІ, тромбоксан, простагландин НI [10]. Виражені структурні зміни артерій дрібного калібру товстої кишки через місяць після резекції 58,1% паренхіми печінки свідчили про їхню особливу функціональну активність при перерозподілі кровотоку в умовах пострезекційної портальної гіпертензії. Потовщення стінки вказаних судин та звуження їх просвіту відбувалися за рахунок збільшення товщин медії, адвентиції, а також посилення тонусу, гіперплазії та гіпертрофії гладком'язових клітин. Виражена звивистість внутрішньої еластичної мембрани досліджуваних артерій свідчила про їх посилений тонус. Пошкодження значної кількості ендотеліоцитів $(33,30 \pm 0,24)$ \% призводило до їхньої дисфункції, блокади NO-синтази, зменшення синтезу NO, активації процесів його деградації, посилення синтезу вазоконстрикторів: ендотеліну, ангіотензину-ІІ, тромбоксану, простагландину $\mathrm{Hl}$, що посилювало спазм, звуження судин та суттєво погіршувало кровопостачання органа і ускладнювалося гіпоксією [10]. Описані структурні зміни артерій дрібного калібру товстої кишки суттєво впливали на регуляцію кровотоку в умовах пострезекційної портальної гіпертензії та забезпечували у даних патологічних умовах оптимальне кровопостачання органа. Відомо також, що артерії дрібного калібру у неушкоджених органах несуть основне навантаження у регуляції кровообігу та першими і у найбільшому ступені пошкоджуються при патології [4].

Гістологічно в оболонках стінки товстої кишки при пострезекційній портальній гіпертензії спостерігалися виражені судинні розлади, повнокров'я, розширення переважно венозних судин, перивазальні набряки та набряки строми, осередки дистрофічно, некробіотично, апоптично змінених епітеліоцитів, ендотеліоцитів, вогнищеві інфільтрати та розростання сполучної тканини. Відмічалися також набряк ендотеліоцитів, їх дистрофія, некробіоз, десквамація та проліферація. Останнє свідчило про наявність гіпоксії.

Виявлялося також просякання мембран ендотеліоцитів, судинної стінки форменими елементами та білками плазми. У деяких досліджуваних судинах спостерігалися осередки фібриноїдного набряку та некрозу, що свідчило про виражене їх пошкодження.

Висновки. Видалення лівої та правої бокових часток печінки у білих щурів призводить до пострезекційної портальної гіпертензії та вираженого 
Огляди літератури, оригінальні дослідження, погляд на проблему, випадок з практики, короткі повідомлення ремоделювання переважно артерій дрібного калібру товстої кишки, яке характеризується потовщенням їхньої стінки, звуженням просвіту, зниженням індексу Керногана, ураженням ендотеліоцитів, ендотеліальною дисфункцією, погіршанням кровопостачання органа, гіпоксією, дистрофією, некрозом тканин і клітин, вогнищевими клітинними інфільтратами, склерозуванням.

\section{ЛІТЕРАТУРА}

1. Автандилов Г. Г. Основы количественной патологии / Г. Г. Автандилов. - М. : Медицина, 2002. - 240 с.

2. Волченко І. В. Особливості виконання общирних резекцій печінки з урахуванням профілактики післяопераційних ускладнень / І. В. Волченко, В. М. Лихман, Д. І. Скорий, А. М. Шевченко // Харківська хірургічна школа. - 2016. - № 3 (78). - С. 35-39.

3. Гарбузенко Д. В. Морфофункциональная перестройка печеночного сосудистого русла в патогенезе портальной гипертензии при циррозе печени / Д. В. Гарбузенко //. Тер. арх. - 2014. - № 86 (2). - С. 90-95.

4. Гнатюк М. С. Морфометрична оцінка особливостей ремоделювання структур дванадцятипалої кишки при резекції різних об'ємів печінки / М. С. Гнатюк, Л.В. Татарчук, О. Б. Ясіновський // Науковий вісник Ужгородського університету. Серія «Медицина». - 2016. Вип. 1 (53). - С. 92-95.

5. Горальський Л. П. Основи гістологічної техніки і морфофункціональні методи досліджень у нормі і при патології / Л. П. Горальський, В. Т. Хомич, О. І. Кононський. - Житомир : Полісся, 2011. - 288 с.

6. Гржибовский А. И. Сравнение количественных данных двух парных выборок с использованием программного обеспечения Statistica и SPSS: параметрические и непараметрические критерии / А. И. Гржибов-

ский, О. В. Иванов, М. А. Горбатова // Наука и здравоохранение. - 2016. - Т. 3. - С. 5-25.

7. Дзигал О. Ф. Формування полісиндромної недостатності хворих на цироз печінки з портальною гіпертензією / О. Ф. Дзигал // Вісник наукових досліджень. 2017. - № 2. - С. 88-92.

8. Хірургічне лікування вогнищевого ураження печінки: аналіз результатів та перспективи / О. І. Дронов, С. В. Земсков, Ю. П. Бакунець, П. П. Бакунець // Клінічна хірургія. - 2016. - № 1. - С. 28-31.

9. Колеснік О. О. Досвід виконання резекції печінки на метастатичний колоректальний рак / О. О. Колеснік, А. А. Бурлака, А. В. Лукашенко, В. В. Приймак // Клінічна онкологія. - 2015. - № 2 (8). - С. 8-13.

10. Охотнікова О. М. Ендотеліальна дисфункція як фактор розвитку тяжкого перебігу прогнозу системних васкулітів у дітей / О. М. Охотнікова, О.В.Поночевна, К. В. Меліна // Клінічна імунологія. Алергологія. Інфектологія. - 2017 - № 2 (99). - С. 46-52.

11. Feng R. T. Molecular mechanism of low doze ionizing radiation in order to control bionegative effects to the organism and related human diseases / R. T. Feng, K. I. Weng // International Journal of Radiation Biology. 2015. - Vol. 91. - P.13-27.

\section{REFERENCES}

1. Avtadnilov, G.G. (2002). Osnovy kolichestvennoy patologicheskoy anatomii [Basis of Quantitative Pathological Anatomy]. Moscow: Meditsyna [in Russian].

2. Volchenko, I.V., Lykhman, V.M., Skoryy, D.I., \& Shevchenko, A.M. (2016). Osoblyvosti vykonannya obshchyrnykh rezektsiy pechinky z urakhuvanniam profilaktyky pisliaoperatsiinykh uskladnen [Peculiarities of performing extensive liver resections taking into account the prevention of postoperative complications]. Kharkivska khirurhichna shkola - Kharkiv Surgical School, 3 (78), 35-39 [in Ukrainian].

3. Garbuzenko, D.V. (2014). Morfofunktsionalnaya perestroyka pechenochnogo sosudistogo rusla v patogeneze portalnoy gipertenzii pri tsirroze pecheni [Morphofunctional rearrangement of the hepatic vasculature in the pathogenesis of portal hypertension in liver cirrhosis]. Ter. Arkh. Ter. Archive, 86 (2), 90-95 [in Russian].

4. Hnatiuk, M.S., Tatarchuk, L.V. Yasinovskyy, O.B. (2016). Morfometrychna otsinka osoblyvostei remodeliu-

vannia struktur dvanadtsiatypaloi kyshky pry resektsii riznykh obiemiv pechinky [Morphometric evaluation of the features of remodeling of duodenal structures during resection of different volumes of the liver]. Naukovyi visnyk Uzhhorodskoho universytetu. Seriia "Medytsyna" - Scientific Herald of Uzhhorod University. Series "Medicine", 1 (49), 3-5 [in Ukrainian].

5. Goralsky, L.P., Khomich, V.T., \& Kononsky, O.I. (2011). Osnovy histolohichnoi tekhniky i morfofunktsionalni metody doslidzhen u normi i pry patolohii [Fundamentals of histological technique and morphofunctional research methods in normal and in pathology]. Zhytomyr: Polissia [in Ukrainian].

6. Grzhibovskiy, A.I., Ivanov, O.V., \& Gorbatova, M.A. (2016). Sravneniye kolichestvennykh dannykh dvukh parnykh vyborok s vnedreniyem programmnogo obespecheniya Statistica i SPSS: parametricheskiye i neparametricheskiye kriterii [Comparison of quantitative data of two paired samples using Statistica and SPSS software: parametric 
Огляди літератури, оригінальні дослідження, погляд на проблему, випадок з практики, короткі повідомлення and nonparametric criteria]. Nauka i zdravookhraneniye Science and Healthcare, 3, 5-25 [in Russian].

7. Dzyhal, O.F. (2017). Formuvannia polisyndromnoi nedostatnosti khvorykh na tsyroz pechinky z portalnoiu hipertenziieiu [Formation of polysyndromic insufficiency of patients with liver cirrhosis with portal hypertension]. Visnyk naukovykh doslidzhen - Bulletin of Scientific Research, 2, 88-92 [in Ukrainian].

8. Dronov, O.I., Zemskov, S.V., Bakunets, Y.P., \& Bakunets, P.P. (2016). Khirurgicheskoye lecheniye ochagovogo porazheniya pecheni analiz rezultatov i perspektivy [Surgical treatment of focal liver disease: analysis of results and prospects]. Klinicheskaya khirurgiya - Clinical Surgery, 1, 28-31 [in Ukrainian].

9. Kolesnik, O.O., Burlaka, A.A., Lukashenko, A.V., \& Pryymak, V.V. (2015). Dosvid vykonannia rezektsii pechinky

na metastatychnyi kolorektalnyi rak [Experience of liver resection for metastatic colorectal cancer]. Klinichna onkolohiia - Clinical Oncology, 2 (8), 8-13 [in Ukrainian].

10. Okhotnikova, O.M., Ponochevna, O.V., \& Mellina, K.V. (2017). Endotelialna dysfuntsiia yak faktor rozvytku tiazhkoho perebihu prohnozu systemnykh vaskulitiv u ditei [Endothelial dysfunction as a factor in the development of severe prognosis of systemic vasculitis in children]. Klinichna immunolohiia. Alerholohiia. Infektolohiia Clinical Immunology. Allergology. Infectology, 2 (99), 46-52 [in Ukrainian].

11. Feng, R.T., \& Weng, K.I. (2015). Molecular mechanism of low doze ionizing radiation in order to control bionegative effects to the organism and related human diseases International Journal of Radiation Biology, $91,13-27$

\section{ОСОБЕННОСТИ КОЛИЧЕСТВЕННЫХ МОРФОЛОГИЧЕСКИХ ИЗМЕНЕНИЙ АРТЕРИЙ ТОЛСТОЙ КИШКИ ПРИ РЕЗЕКЦИИ РАЗЛИЧНЫХ ОБЪЕМОВ ПАРЕНХИМЫ ПЕЧЕНИ}

\section{๑М. С. Гнатюк, О. М. Процайло, Л. В. Татарчук, Н. Я. Монастырская}

Тернопольский национальный медицинский университет имени И. Я. Горбачевского МОз Украины

РЕЗЮМЕ. Удаление больших объемов печени приводит к портальной гипертензии, кровотечениям из варикозно расширенных вен пищевода, желудка, прямой кишки, асциту, спленомегалии и структурной перестройке органов бассейна воротной печеночной вены. Толстая кишка - орган, венозный дренаж от которого осуществляется через воротную печеночную вену и гемодинамические расстройства в ней осложняются различными структурно-функциональными изменениями, а мофология артериального русла толстой кишки при резекции различных объёмов печени изучена недостаточно.

Цель - количественными морфологическими методами изучить особенности структурной перестройки артерий толстой кишки при резекции различных объемов паренхимы печени.

Материал и методы. Морфологически исследованы артерии толстой кишки 60 крыс, которые были поделены на три группы. 1 группа - 20 интактных животных, 2 - 20 крыс после удаления 31,5 \% паренхимы печени, 3 20 животных после резекции 58,1 \% паренхимы печени. Эвтаназия животных осуществлялась кровопусканием в условиях тиопенталового наркоза через 1 месяц после начала опыта. Из толстой кишки изготавливали микропрепараты, на которых морфометрически определяли внешний и внутренний диаметры артерий среднего и мелкого калибров, толщину медии, адвентиции, высоту эндотелиоцитов, диаметр их ядер, ядерно-цитоплазматические соотношения в этих клетках, относительный объем поврежденных эндотелиоцитов. Количественные показатели обрабатывали статистически.

Результаты. Установлено, что удаление 58,1 \% паренхимы печени приводило к развитию пострезекционной портальной гипертензии и выраженной структурной перестройке преимущественно артерий мелкого калибра толстой кишки, которая характеризовалась значительным ростом толщины их стенки, медии и адвентиции, уменьшением просветов на 26,6 \%, индекса Керногана - на 52,3 \% ( $<20,001)$. Ядерно-цитоплазматические соотношения в эндотелиоцитах при этом увеличились на 7,5 \% ( $<<0,01)$, относительный объем поврежденных эндотелиоцитов - в 14,5 раза $(p<0,001)$.

Выводы. Удаление левой и правой боковых долей печени у белых крыс приводит к пострезекционной портальной гипертензии и выраженному ремоделированию преимущественно артерий мелкого калибра толстой кишки, характеризующемуся утолщением их стенки, сужением просвета, снижением индекса Керногана, поражением эндотелиоцитов, эндотелиальной дисфункцией, ухудшением кровоснабжения органа, гипоксией, дистрофией, некрозом тканей и клеток, очаговыми клеточными инфильтратами, склерозированием.

КЛЮчЕВЫЕ СЛОВА: резекция печени; толстая кишка; артерии; морфометрия. 
Огляди літератури, оригінальні дослідження, погляд на проблему, випадок з практики, короткі повідомлення PECULIARITIES OF QUANTITATIVE MORPHOLOGICAL CHANGES OF ARTERIES
OF THE COLON AT RESECTIONS OF DIFFERENT VOLUMES OF LIVER PARENCHYMA

\author{
@M. S. Hnatjuk, O. M. Protsaylo, L. V. Tatarchuk, N. Ya. Monastyrska \\ I. Horbachevsky Ternopil National Medical University
}

SUMMARY. Removal of large volumes of liver leads to portal hypertension, bleeding from varicose veins of the esophagus, stomach, rectum, ascites, splenomegaly and structural rearrangement of the organs of the portal hepatic vein. The large intestine is an organ from which venous drainage is performed through the portal hepatic vein and hemodynamic disorders in it are complicated by various structural and functional changes, and the morphology of the arterial bed of the large intestine at resection of various volumes of the liver is insufficiently studied.

The aim of the study - quantitative morphological methods to study the features of the structural rearrangement of the arteries of the large intestine at resection of different volumes of the liver parenchyma.

Material and Methods. Morphologically examined arteries of the colon of 60 rats, which were divided into 3 groups. Group 1 - 20 intact animals, 2 - 20 rats after removal of $31.5 \%$ of the liver parenchyma, 3-20 animals after resection of $58.1 \%$ of the liver parenchyma. Euthanasia of animals was performed by bloodletting under thiopental anesthesia 1 month after the start of the experiment. Micronutrents were made from the large intestine, which morphometrically determined the outer and inner diameters of arteries of medium and small calibers, media thickness, adventitia, height of endothelial cells, diameter of their nuclei, nuclear-cytoplasmic ratios in these cells, relative volume of damaged cells. Quantitative indicators were processed statistically.

Results. It was found that the removal of $58.1 \%$ of the liver parenchyma led to the development of postresection portal hypertension and severe structural rearrangement of mainly small arteries of the large intestine, which was characterized by a significant increase in wall thickness, media and adventitia, a decrease in lumens by $26.6 \%$, Kernogan index - in $52.3 \%$ ( $p<0.001)$. Nuclear-cytoplasmic ratios in endotheliocytes increased by $7.5 \%(p<0.01)$, the relative volume of damaged endotheliocytes -14.5 times $(p<0.001)$.

Conclusions. Removal of the left and right lateral lobes of the liver in white rats leads to postresection portal hypertension and severe remodeling of mainly small arteries of the large intestine, which is characterized by thickening of their wall, narrowing of the lumen, decreased Kernogan index, blood disturbances, endothelial cells, endothelial cell lesions dystrophy, necrosis of tissues and cells, focal cellular infiltrates, sclerosis.

KEY WORDS: liver resection; large intestine; arteries; morphometry. 